\title{
ケルビンフォース顕微鏡を用いた金属表面の 腐食反応の解析
}

\author{
升田 博之 \\ 金属材料技術研究所 函 305-0047 茨城県つくば市千現 1-2-1
}

(2000 年 11 月 14 日受理)

\section{Analysis of Corrosion Reaction on Metal by Kelvin Force Microscopy}

\author{
Hiroyuki MASUDA \\ National Research Institute for Metals \\ 1-2-1 Sengen, Tsukuba, Ibaraki 305-0047
}

(Received November 14, 2000)

\begin{abstract}
Kelvin force microscopy (KFM) as one of the AFMs is very useful for corrosion study, because it provides the surface morphology and potential distribution with high accuracy. The mechanism of initial atmospheric corrosion of steels accelerated by sea salt particles is not well known. In-situ observations of the corrosion initiated with small droplets of artificial sea water and dilute $\mathrm{MgCl}_{2}$ solution were made under low relative humidity condition by using KFM and super Kelvin force microscopy (SKFM) which we have developed recently. At the same time, EDX analysis and optical microscope observation were made. The results show that the morphology of corrosion can be classified into 3 types. The potential of corroding part is more negative than those of other parts. Iron chloride is formed at the corroding part and water is supplied by the deliquescence of iron chloride.
\end{abstract}

1. 緒言

原子間力顕微鏡 (AFM) により表面電位を測定する 手法はケルビンフォース顕微鏡 $(\mathrm{KFM})$ もしくはエレ キトリックフォース顕微鏡 (EFM) と呼ばれている。 この手法は, Martin ら"1によって最初に用いられ，多く の分野への適用 ${ }^{2 \sim 5}$ がなされてきたが, 腐食分野へ適用 した報告 ${ }^{6 \sim 10}$ はあまりなされていない。KFM を用いる ことにより形状と電位分布の変化が非常に正確に取得で きるので, 腐食研究に非常に有用である。しかし, 通常 の KFM を用いた場合, 水平方向の走査領域が最大 100 $\times 100 \mu \mathrm{m}$ 程度と小さいので, 非常に初期の腐食状態し か観察できず, 腐食の全体像をつかめないという欠点が あった。光こで, この欠点を補うため走査領域が最大 1 $\times 1 \mathrm{~cm}$ と非常に大きいスーパーケルビンフォース顕微 鏡（SKFM）を開発した。この装置を用いれば，小さな

E-mail: hm@nrim.go.jp
液滴から発生する腐食過程の全容を観察することが可能 である。ここでは，KFM およびSKFM を用いた金属の 腐食解析を紹介する。

\section{2. 非接触測定の原理}

本実験で用いた表面電位測定法は Yasutake ら ${ }^{11}$ によ つて開発されたもので, 表面形状および表面電位を同時 に非接触で取得することが可能である。Fig. 1 にダイナ ミックフォースモード下のフォースカーブを示すが , 通 常用いられるタッピングモードと呼ばれる手法では, 図 で明らかなように非接触領域では探針と試料間の距離に 伴う振幅変化がほとんどないため, 非接触モードで像を 取ることはできない。一方，KFMやSKFM では探針に バイアス電圧が常にかかっているため探針と試料間に強 い引カが働き, フォースカーブが通常の場合と異なり非 接触領域での探針と試料間の距離に伴う振幅変化が大き い。このことにより非接触で像を得ることが可能となる。 Fig. 2 に非接触モードで取得した SUS 316 L ステンレス 
鋼に直径 $1 \mathrm{~mm}$ 近くもある $\mathrm{MgCl}_{2}$ の液滴を付着させたと きの形状像と電位分布像を示す。このように SKFM は 走査電子顕微鏡では液滴が乾燥するため, またレーザ顕

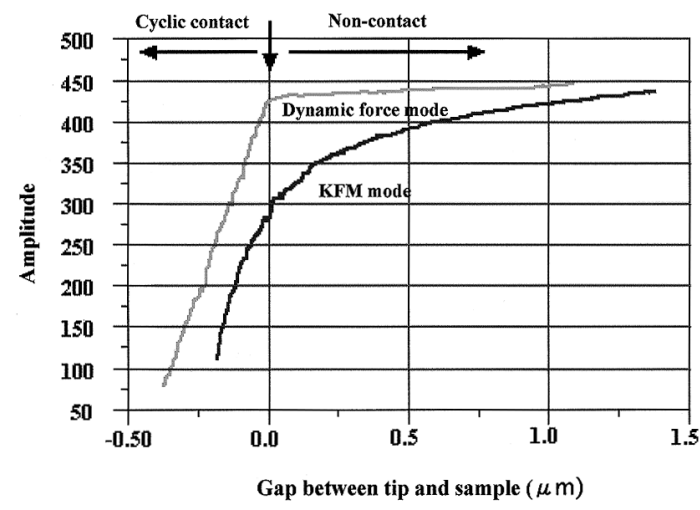

Fig. 1 Force curves under dynamic force mode and KFM mode.
微鏡では光の透過や干渉のため測定が不可能な透明な液 滴の 3 次元形状を高精度に取得することが可能である。

\section{3. 実 験 手 法}

\section{1 SKFM 装置}

SKFM では探針を所定の位置にセットしたのちX-Y 方向の走査を精密 X-Y パルスステージで行うか通常の ピエゾスキャナーで行うかを選択できる。光のため，10 $\mathrm{nm}$ から $1 \mathrm{~cm}$ までの非常に広い走査範囲をカバーするこ とが可能である。精密 X-Y パルスステージで走査する 場合, 最小移動量は $0.1 \mu \mathrm{m}$ でピエゾスキャナーは Z 方 向のみ制御する。使用したピエゾスキャナーは 2 種類で 3 軸の $100 \times 100 \times 12 \mu \mathrm{m}$ と 1 軸の $0 \times 0 \times 40 \mu \mathrm{m}$ である。 後者のスキャナーはピエゾの非直線性を自動的に補正す る静電容量型のセンサーが内蔵されている。探針は $\mathrm{Si}$ に金コートしたものを用いた。また凹凸が非常に大きい 場合は Fig. 3 に示すような走査電子顕微鏡の点ビームモ

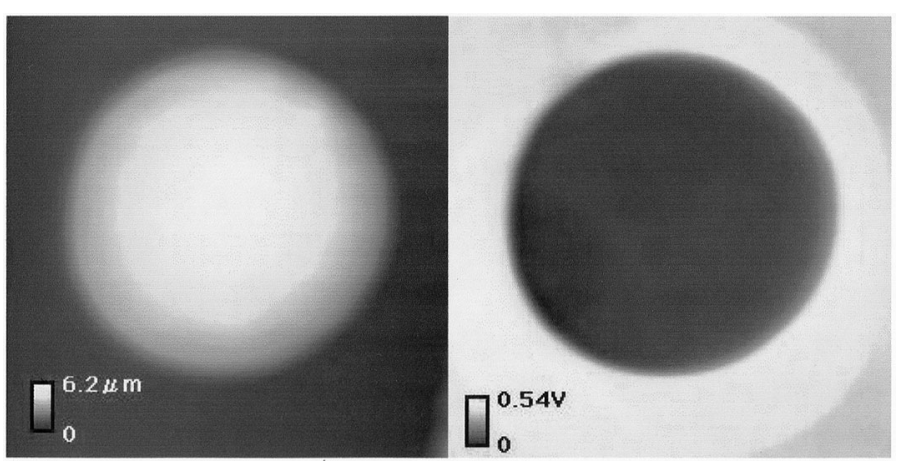

Fig. 2 Example of SKFM image of $\mathrm{MgCl}_{2}$ droplet obtained by non-contact mode $(1.6 \mathrm{~mm} \times 1.6 \mathrm{~mm})$. Left: topography, right: potential distribution image.

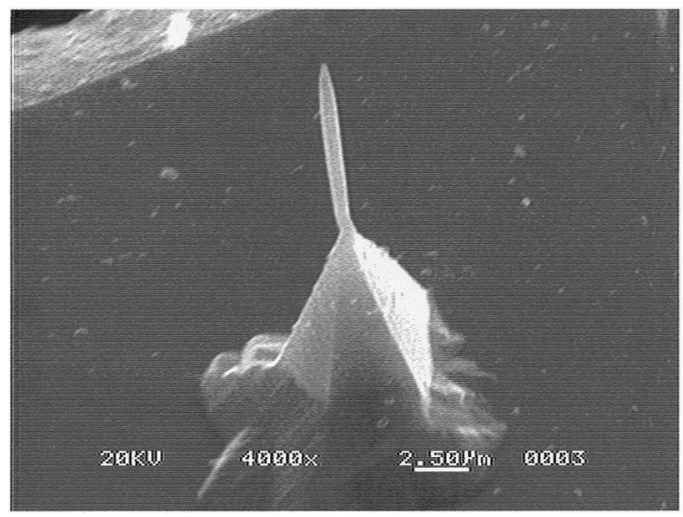

Fig. 3 SEM image of super tip produced by carbon contamination.

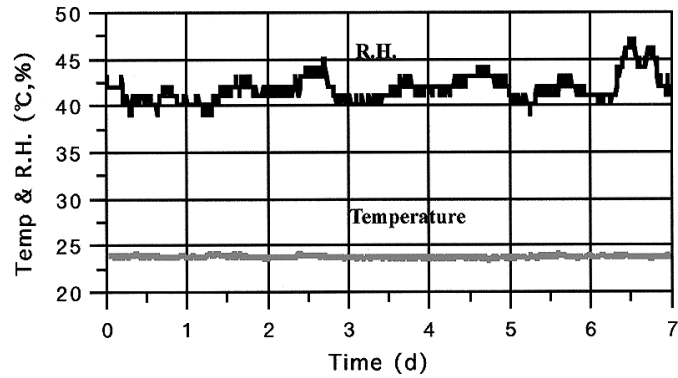

Fig. 4 Example of the change of temperature and humidity during experiment. 
ードを用いて先端にカーボンウイスカーを形成させた探 針を用いた。これは真空容器中のカーボンコンタミネー ションを利用する方法で , 形成させたい場所に点ビーム モードで長時間電子線を当てるとカーボンウィスカーが 形成される。

3.2 大気腐食試験

供試材として $99.998 \%$ の超高純度鉄を用いた。腐食
試験は粗さ $0.3 \mu \mathrm{m}$ まで研磨した試験片に直径 $0.1 \mathrm{~mm}$ か ら $0.5 \mathrm{~mm}$ の人工海水もしくは $\mathrm{MgCl}_{2}$ 水溶液を試料に付 着させ, Fig. 4 に示すような温度約 $24^{\circ} \mathrm{C}$, 相対湿度 35 $\%$ から $45 \%$ の低湿度下の大気中に放置して腐食の進展 をKFM および SKFM 観察した。またほぼ同時刻に同じ 場所の EDX 分析および光学顕微鏡観察を行った。

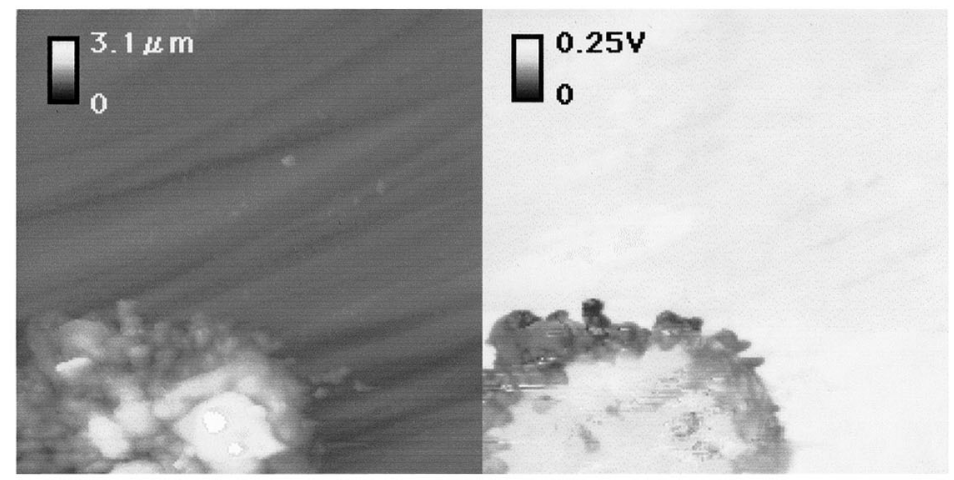

(a) At the beginning

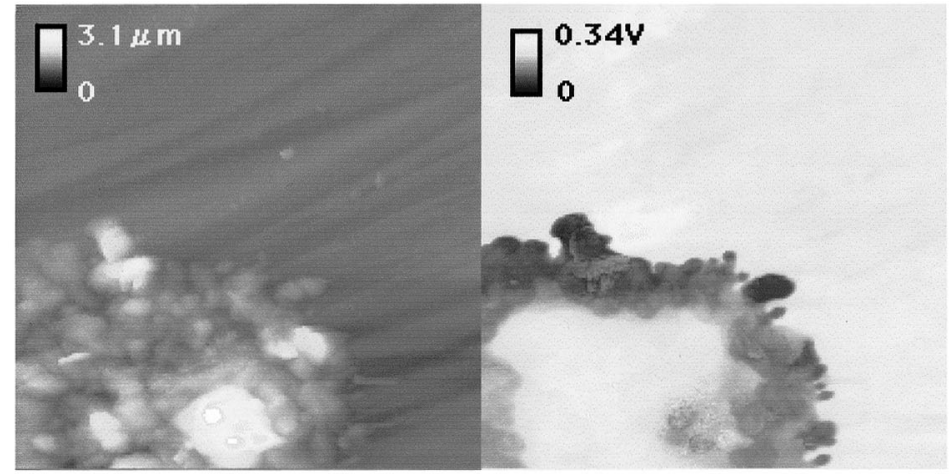

(b) After 2 hours

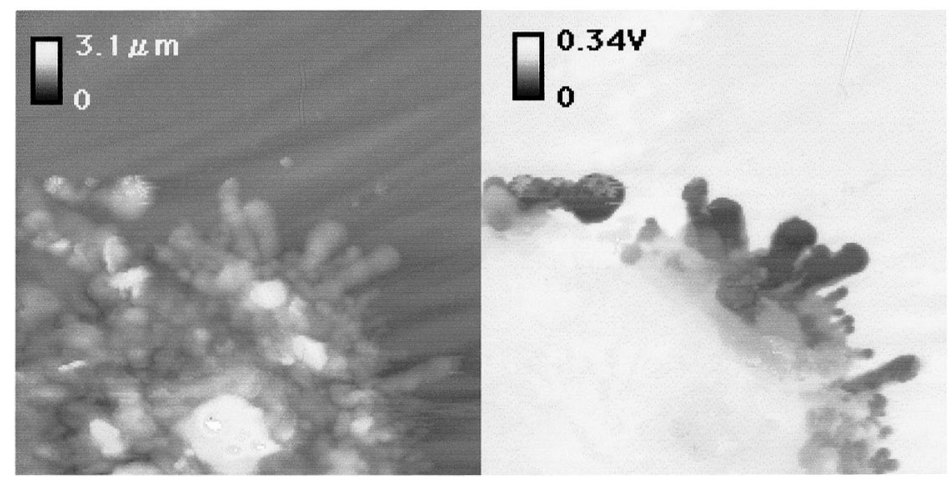

(c) After 4 hours

Fig. 5 SKFM images of atmospheric corrosion of pure iron with attaching artificial sea water. Image size: $40 \times 40 \mu \mathrm{m}$. Left: topography, right: potential distribution image. 
4. 結果と考察

\section{1 KFM}

腐食形態は人工海水および $\mathrm{MgCl}_{2}$ 水溶液とも以下の 3 種類に分類される。

（1）腐食が内部に孔食状に進行するもの。

（2）腐食がテーブルに液体をこぼした時のように円盤
状に進行するもの。

(3) 腐食が系状に進行するもの。

Fig. 5 に人工海水の液滴の外側に円盤状に腐食が進行 しているときの KFM 連続観察の例を示す。図中で左側 が形状像で明るい部分が凸の部分である。また右側が表 面電位分布図で明るい部分が貴な部分である。表面形状 の変化や表面電位分布から明白なように腐食している部

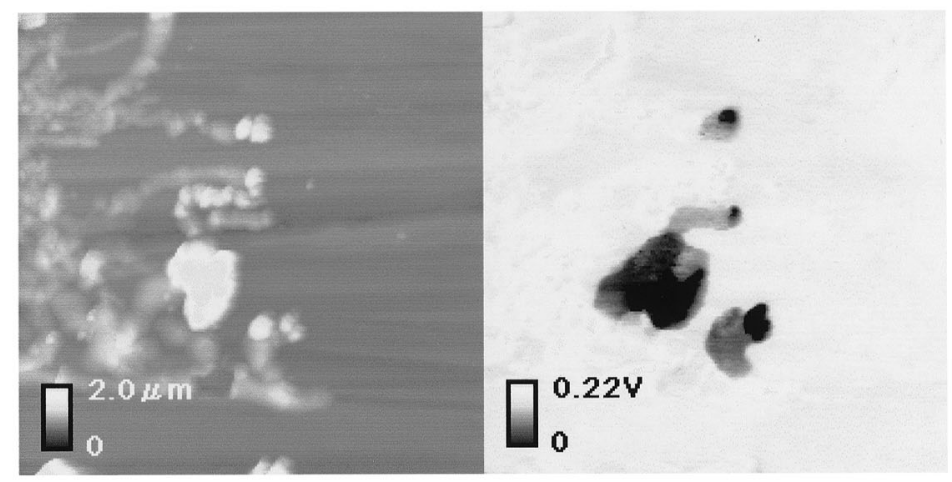

(a) At the beginning

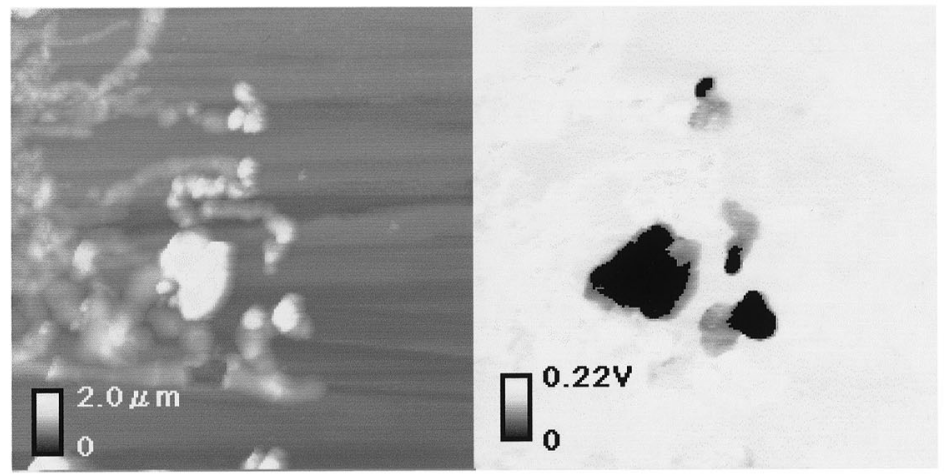

(b) After 10 hours

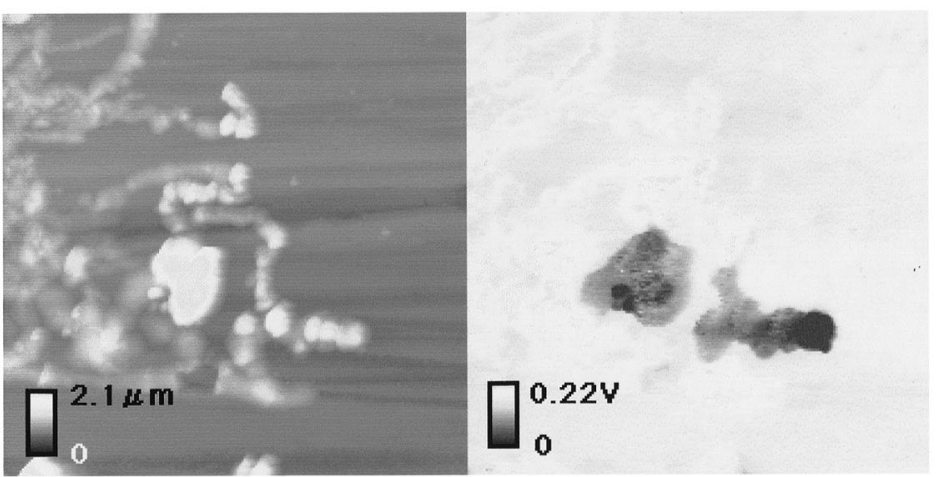

(c) After 20 hours

Fig. 6 SKFM images of atmospheric corrosion of pure iron with attaching artificial sea water. Image size: $50 \times 50 \mu \mathrm{m}$. Left: topography, right: potential distribution image. 
分の電位は他の部分に較べて卑である。形状変化からわ かるように腐食は表面上を進行し，腐食が止まると電位 は貴の方向に移動することがわかる。Fig. 6 に人工海水 の液滴の外側に腐食が食状および系状に進行している ときの KFM 連続観察の例を示す。この場合も円盤状に 腐食が進行しているときと同樣に腐食が進行している場 所の電位が他の場所に較べて卑で, 腐食が止まると電位
は貴の方向に移動する。腐食が進行しているときアノー ド部 (腐食部) とカソード部 (還元反応部) が存在する。 Fig. 6 の系状腐食の場合を考えると系状腐食の先端部か らすぐ後に腐食が進行している部分より電位がやや貴な 部分が観察されカソード部かと思われる。しかし系状の 腐食部を更に高倍率で観察すると Fig. 7 に示すように腐 食部内部に電位の異なる部分が観察され, 電位分布 (電

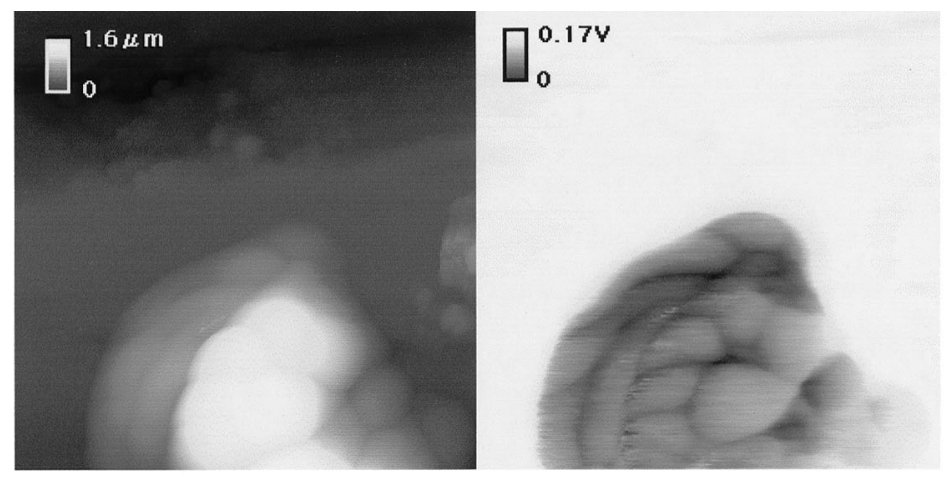

(a) At the beginning

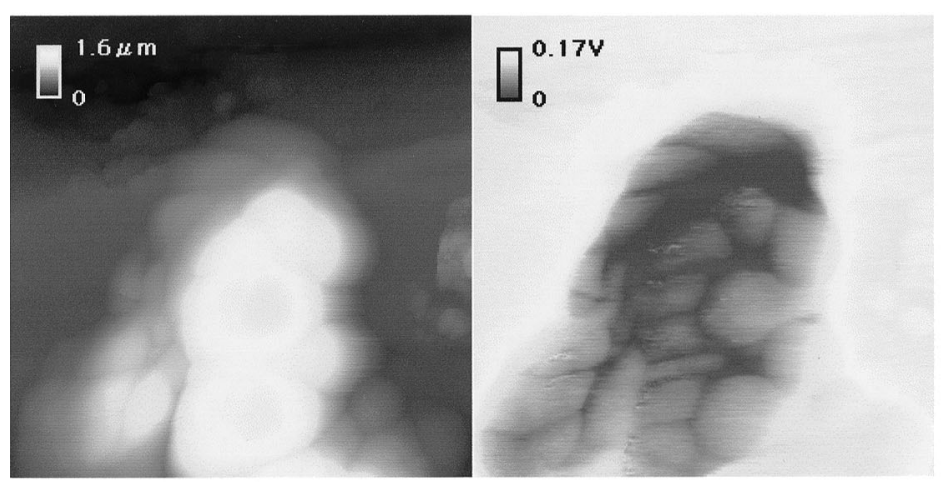

(b) After 2.5 hours

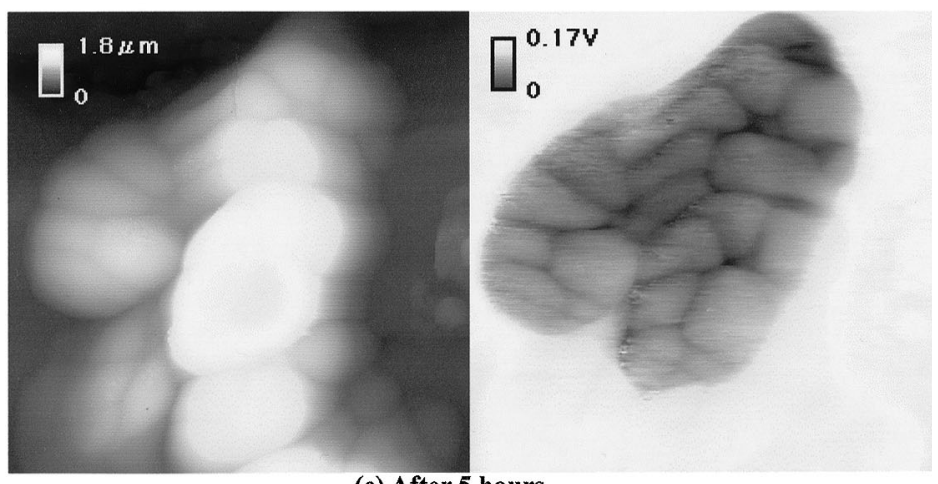

(c) After 5 hours

Fig. 7 KFM images of atmospheric corrosion of pure iron with attaching artificial sea water. Image size: $5 \times 5 \mu \mathrm{m}$. Left: topography, right: potential distribution image. 
位の貴な部分, 卑な部分) も時間の経過に伴って変化し ていることから腐食部内部でアノード部, カソード部を 形成している可能性もあることがわかる。

\section{2 SKFM}

KFM では走査範囲が最大 $100 \mu \mathrm{m}$ と限定されるため， このサイズを越える大きさの液滴からの腐食の発生を観 察することは困難である。光こでSKFM を用いて液滴
からの腐食の発生・成長を観察した。Fig. 8 に0.01\% $\mathrm{MgCl}_{2}$ 液滴を付着させたときの連続 SKFM 観察を示す。 液膜厚さは $30 \mathrm{~nm}$ から $100 \mathrm{~nm}$ 程度である。Fig. 8 (a) は液滴を付着させて 20 分後に観察したときの SKFM 像 である。液滴が付着した場所の電位は付着していない場 所の電位より約 $260 \mathrm{mV}$ 卑である。腐食の発生が液滴内 部で多数起こっていることが観察される。液滴内部で発

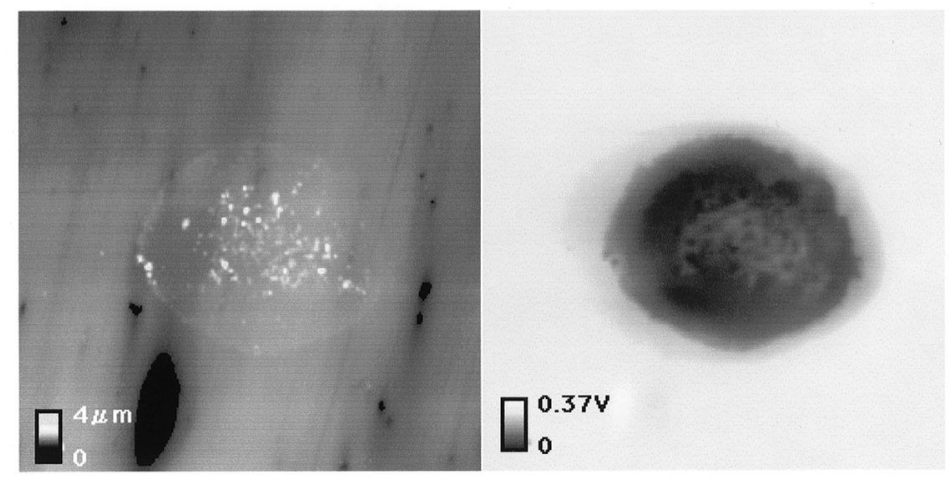

(a) At the beginning

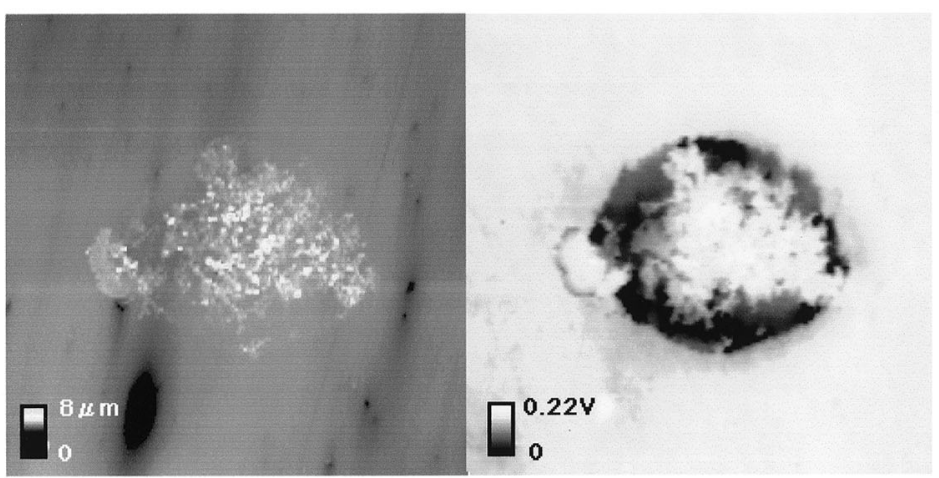

(b) After 15 hours

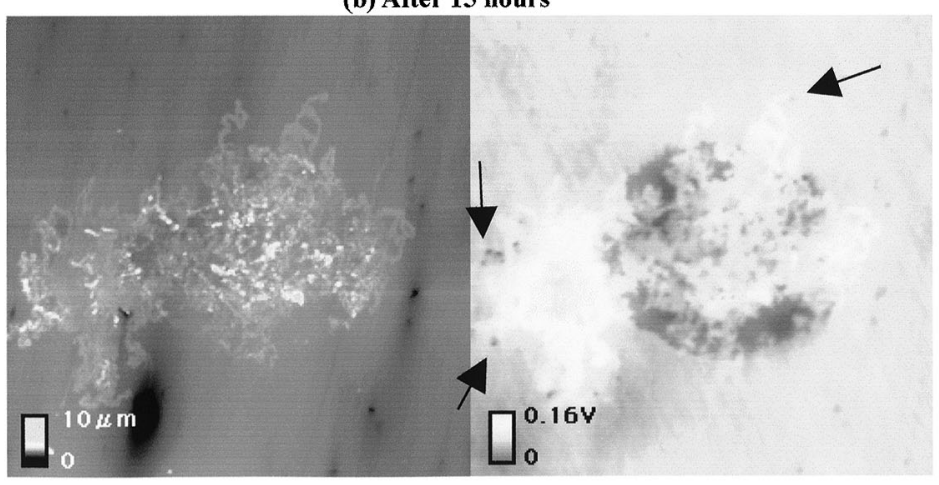

(c) After 50 hours

Fig. 8 SKFM images of atmospheric corrosion of pure iron with attaching $0.01 \%$ $\mathrm{MgCl}_{2}$. Image size: $0.4 \times 0.4 \mathrm{~mm}$. Left: topography, right: potential distribution image. 


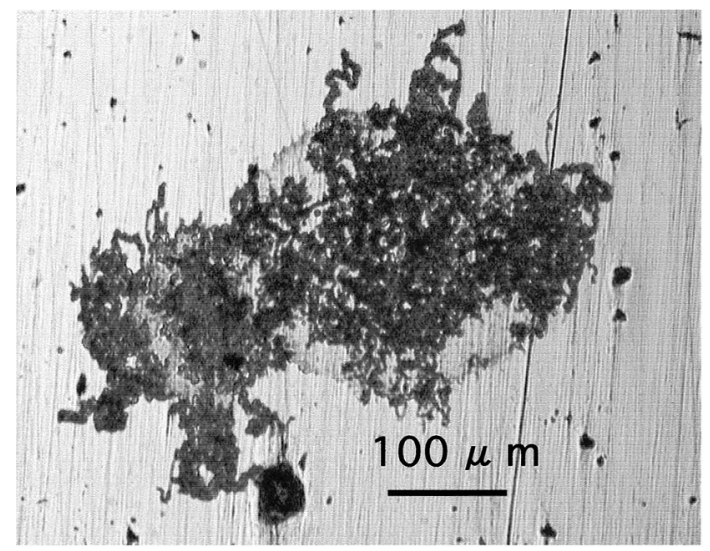

Fig. 9 Optical microscope image of atmospheric corrosion of pure iron $56 \mathrm{~h}$ after attaching $0.01 \% \mathrm{MgCl}_{2}$.

生した腐食は系状に成長し液滴内部全面に腐食は拡大す る。腐食が停止した場所の電位は貴の方向に移動する。 また Fig. 8 (b) で観察されるように液滴を付着させて 15 時間後には一部の箇所では液滴の外側に円盤状の腐食が 成長し，KFMで観察したように腐食が進行している部 分の電位が卑になっていることがわかる。更に時間が経 過して 50 時間後では Fig. 8 (c) で矢印で示すように系 状の腐食が液滴外部に発達し, 進行している部分の電位 が KFM 観察と同樣に他の部分に較べて卑であることが わかる。Fig. 9 に 52 時間後の光学顕微鏡像を示す。SKFM 像が観察結果とよい対応があることがわかる。

\section{4. $3 \mathrm{EDX}$ 分析}

大気腐食の機構を調べるため SKFM 観察と EDX 分析 を併用した。電位と形状の変化から腐食が進行している 部分を同定し, 兴の部分の EDX 分析を行うことにより 大気腐食の進行の機構を推定した。Fig. 10 (a) にSKFM 像を示すが,円盤状の腐食が進行していることがわかる。 腐食している部分の EDX 分析の結果を Fig. 10 (b) に 示す。腐食が進行している部分は $\mathrm{Cl}$ イオンの濃化が観 察される。しかし Mg イオンはほとんど観察されない。

Fig. 11 (a) は EDX 分析後, 試料の同じ場所を 8 時間後 にふたたび観察したときの SKFM 像である。試料は EDX 分析のため長時間真空中に置かれ完全に乾燥された。し かし $40 \%$ という低い相対湿度に放置されるやいなや EDX 分析する前と同じ場所から腐食は進行している。

Fig. 11 (b) にEDX 分析の結果を示すが, 腐食が進行し ている部分は $\mathrm{Cl}$ イオンの濃化が観察されるが $\mathrm{Mg}$ イオ ンはほとんど観察されない。

\section{4 大気腐食機構}

EDX 分析の結果から塩化鉄が腐食の進行している場

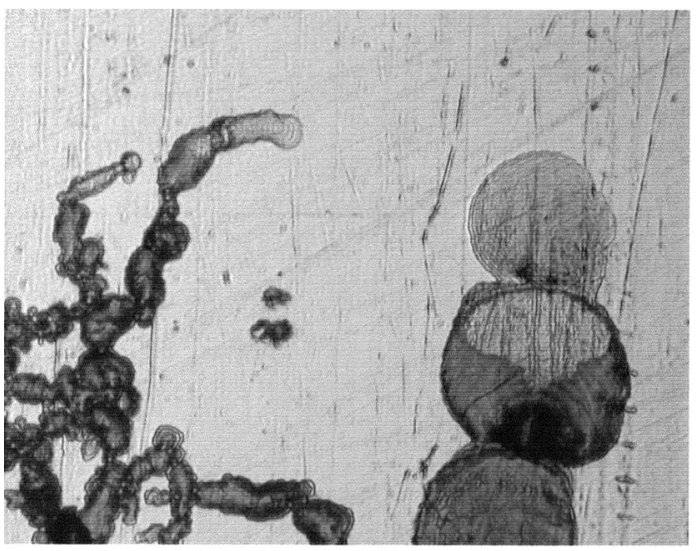

Fig. 12 Optical microscope image of atmospheric corrosion of pure iron attaching $0.01 \% \mathrm{MgCl}_{2}$.

所に形成されていることがわかる。塩化鉄は潮解性が強 いので, 低い相対湿度下でも水分を腐食部に補給するこ とができ腐食の進行が可能になる。また鉄の溶解により 腐食部で陽イオンが増加する。電気的中性の条件を満た すために陰イオンの増加が必要である。关のため塩素イ オンの移動が起こる。腐食が液滴の外部で進行する場合， $\mathrm{Cl}$ イオンの増加は起こらないので一定量の塩化鉄で腐 食は進行することになる。腐食が進行している時の反応 として式 (1)，式 (2) および式 (3) が考えられる。

$$
\begin{aligned}
& \mathrm{Fe}+1 / 2 \mathrm{H}_{2} \mathrm{O}+3 / 4 \mathrm{O}_{2} \rightarrow \mathrm{FeOOH} \\
& \mathrm{Fe}+\mathrm{H}_{2} \mathrm{O}+1 / 2 \mathrm{O}_{2} \rightarrow \mathrm{FeOOH}+1 / 2 \mathrm{H}_{2} \\
& \mathrm{FeCl}_{2}+\mathrm{H}_{2} \mathrm{O}+1 / 2 \mathrm{O}_{2} \rightarrow \mathrm{FeOOH}+\mathrm{HCl}
\end{aligned}
$$

このように腐食溶解した鉄イオンは水と酸素と反応し てさび $(\mathrm{FeOOH})$ を形成する。式 (1), 式 (2) の反応 では $\mathrm{Cl}$ イオンの消費は起こらず, 腐食は進行していく ことになる。式（3）の反応では Cl イオンの消費が起こ り，腐食は停止することになる。腐食が定常的に進行し ている時は式 (1) もしくは式 (2) の反応が起こってい ると考えられる。光の時腐食速度はさびの形成速度に依 存することになる。一方, 腐食先端部でも Fig. 11 でわ かるように腐食が停止した場所には EDX 分析で $\mathrm{Cl}$ イオ ンが検出されないことから, 式 (3) の反応で腐食は停 止していると考えられる。Fig. 12 に相対湿度 $75 \%$ 下の 環境で成長している系状腐食の光学顕微鏡写真を示す。 系状腐食の幅は相対湿度が大きいほど一般に大きい。光 の理由として塩化鉄の平衡飽和濃度が相対湿度が高くな るほど低くなり塩化鉄の水溶液量が相対湿度が高いほど 増加するためである。腐食先端部は透明でこの部分を顕 微 FT-IR で分析すると塩化第 1 鉄 $\left(\mathrm{FeCl}_{2}\right)$ に近いこと が, また腐食後方には茶色のさびが形成され，同樣に分 


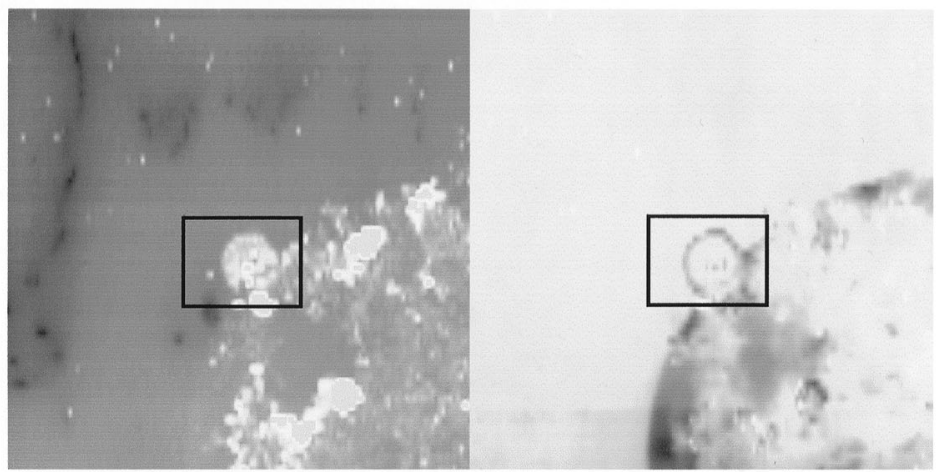

(a) SKFM image of discoidal type of corrosion. Left: topography, right: potential distribution image.

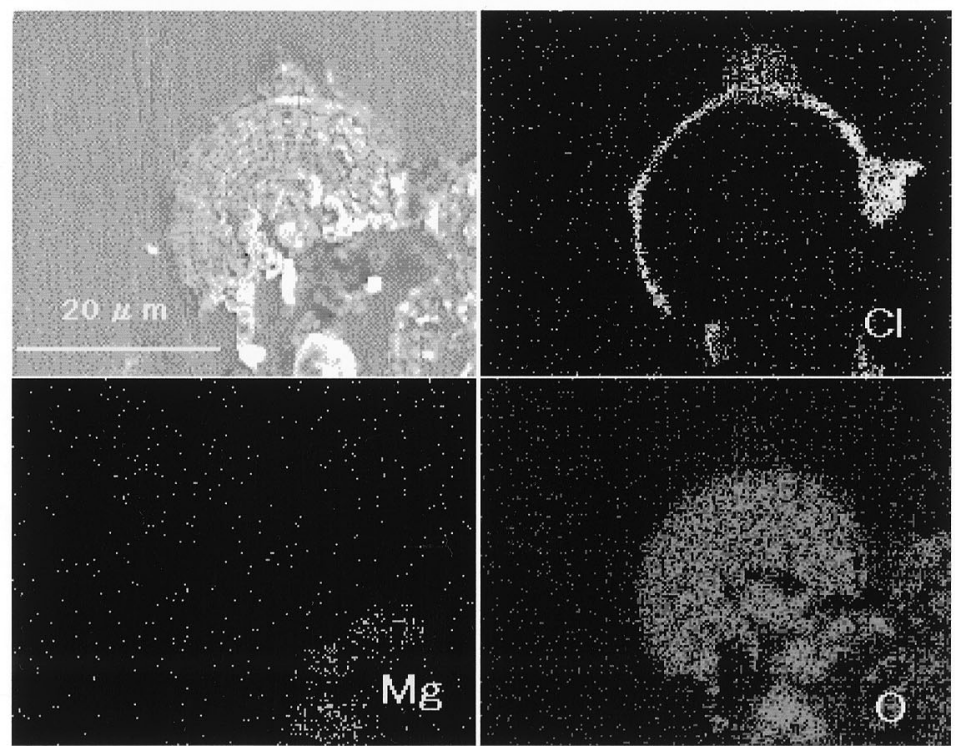

(b) EDX mappping image of discoidal type of corrosion.

Fig. 10 EDX analysis of atmospheric corrosion of pure iron $17 \mathrm{~h}$ after attaching $0.01 \% \mathrm{MgCl}_{2}$.

析すると $\beta$-FOOH であることが確認された。Fig. 13 に SKFM で取得した形状像の時間変化を示す。左側の像は Fig. 12 に示した光学顕微鏡写真を取得後すぐにとった 像である。右側は 4 時間後の像である。腐食が進展して

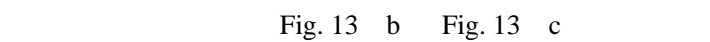
れ图中に示した X 方向および $\mathrm{Y}$ 方向の断面図である。4 時間後の腐食部の高さが低くなっていることから 式(1) もしくは式 (2) で表される反応によりさびが形成され， 塩化鉄の水溶液が前方に押し出され円盤状もしくは系状 の腐食が表面を這うように進行するものと思われる。

\section{5. 結言}

人工海水や希薄 $\mathrm{MgCl}_{2}$ 水溶液の液滴から発生した腐 食の光の場測定を KFMや最近開発したスーパーケルビ ンフォース顕微鏡 (SKFM) を用いて行った。また同時 にEDX 分析と光学顕微鏡観察を行った。光の結果腐食 形態は 3 つに分類される。また腐食部の電位は他の部位 より卑で, 塩化鉄が腐食部で形成され，水分が塩化鉄の 潮解性により補給され腐食が低湿度下で進行することが 判明した。 


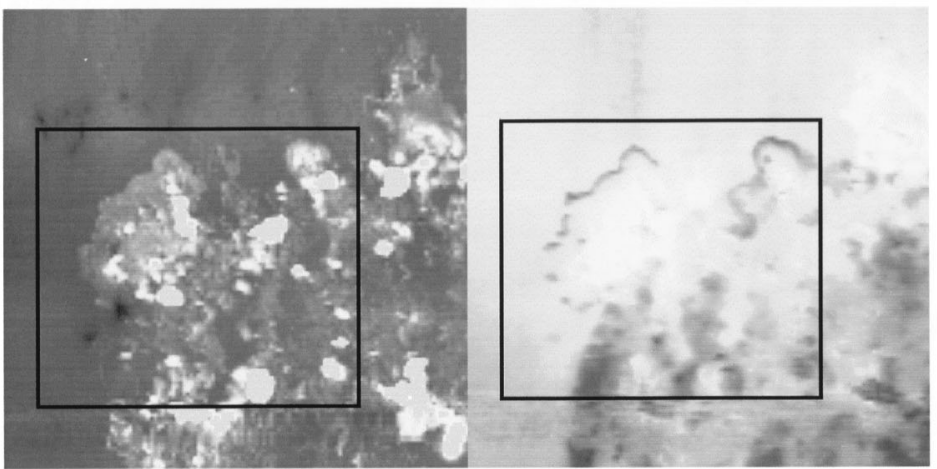

(a) SKFM image of discoidal type of corrosion. Left: topography, right: potential distribution image.

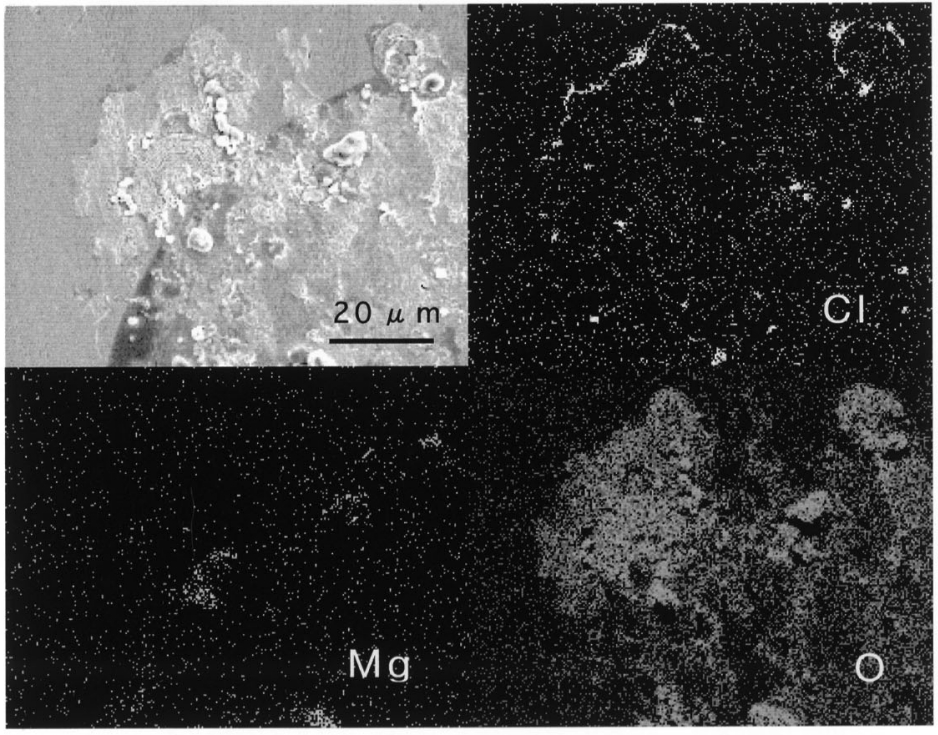

(b) EDX mappping image of discoidal type of corrosion.

Fig. 11 EDX analysis of atmospheric corrosion of pure iron $25 \mathrm{~h}$ after attaching $0.01 \% \mathrm{MgCl}_{2}$.

\section{文献}

1) Y. Martin, D.W. Abraham and H.K. Wickramasinghe: Appl. Phys. Lett. 52, 1103 (1988).

2) M. Nonnenmacher, M.P. O'Boyle and H.K. Wickramasinghe: Appl. Phys. Lett. 58, 2921 (1991).

3) J.M.R. Weaver and D.W. Abraham: J. Vac. Sci. Technol. B 9, 1559 (1991).

4) M. Tanimoto and O. Vatel: J. Vac. Sci. Technol. B 14, 1547 (1996).

5) P. Schmutz and G.S. Frankel: J. Electrochem. Soc. 145,
2285 (1998).

6) P. Schmutz and G.S. Frankel: J. Electrochem. Soc. 145, 2295 (1998).

7) P. Schmutz and G.S. Frankel: J. Electrochem. Soc. 146, 4461 (1999).

8) 升田博之 : 表面科学 18, 72 (1997).

9) H. Masuda: 14th ICC, Paper no. 94.1 (Capetown, South Africa, ICC, 1999).

10) H. Masuda and K. Noda: Electrochemical Society Proc. Volume 99-28 (1999) p. 351.

11) M. Yasutake, D. Aoki and M. Fujihira: Thin Solid Films 273, 279 (1996). 

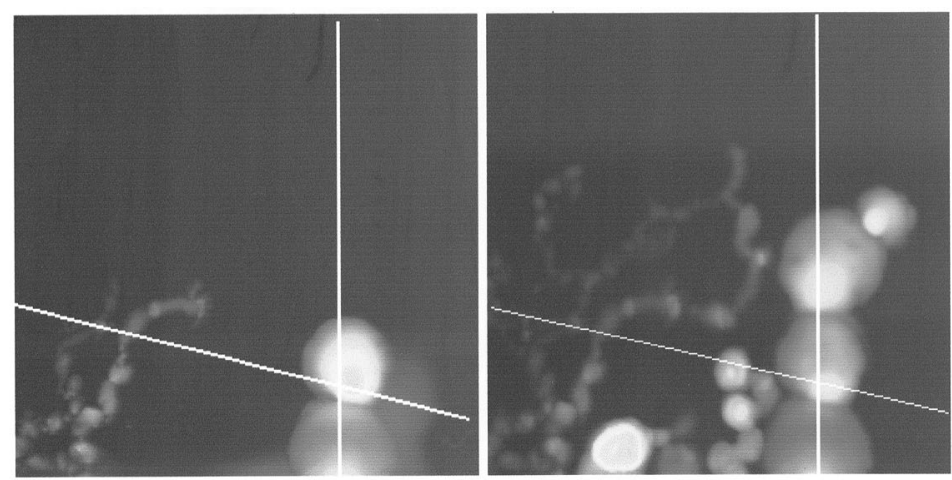

(a) At the beginning (left) and after 8 hours (right).

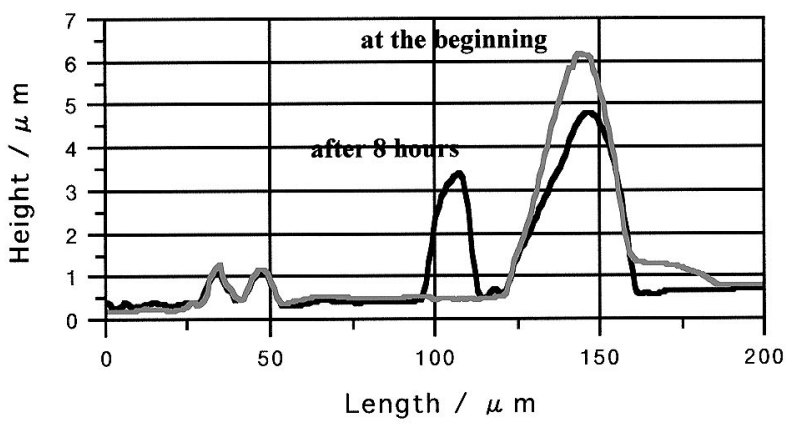

(b) Profile of $\mathrm{X}$ direction.

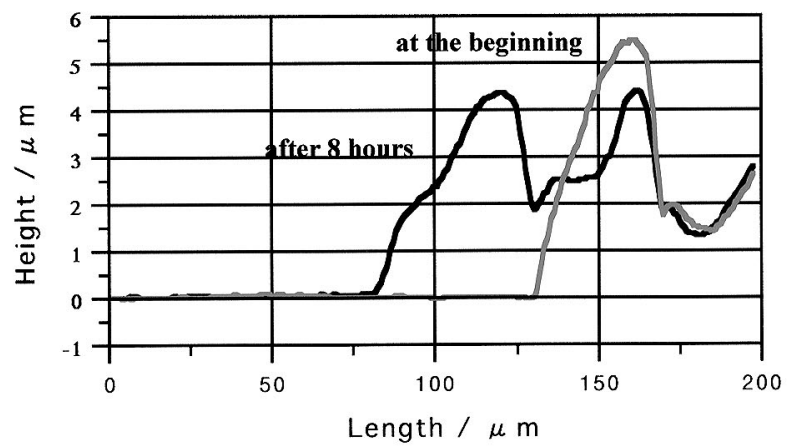

(c) Profile of Ydirection.

Fig. 13 SKFM images (topography) of atmospheric corrosion of pure iron with attaching $0.01 \% \mathrm{MgCl}_{2}$. Image size: $0.2 \times 0.2 \mathrm{~mm}$. 